\title{
THE EFFECT OF MOLYBDENUM DISULFIDE NANOPARTICLES AND SODIUM DODECYL SULFATE ADDITION TOWARDS WEAR PROTECTION PROPERTIES FROM THE SAE 10W-30 STANDARD LUBRICANTS
}

\author{
Susilawati $^{1{ }^{* *}, \text { M. Hanifuddin }}{ }^{2}$ and U. Saragih ${ }^{1}$ \\ ${ }^{1}$ Department of Physics, Faculty of Mathematics and Natural Sciences, Universitas Sumatera \\ Utara, Jl. Bioteknologi No.1, Medan 20155, Indonesia \\ ${ }^{2}$ Pusat Penelitian dan Pengembangan Teknologi Minyak dan Gas Bumi, Jl. Ciledug Raya \\ Kav.109 South Jakarta 12230, Indonesia \\ *E-mail: susilawati@usu.ac.id
}

\begin{abstract}
The use of modified lubricants on the engine could lead to the efficiency of energy use. This research aimed to investigate the effect of molybdenum disulfide $\left(\mathrm{MoS}_{2}\right)$ nanoparticles and Sodium Dodecyl Sulfate (SDS) addition to the SAE-10W-30 standard lubricant that is formulated from three basic oils (HVI-60, HVI-95, and Yubase-8). The preparation of SAE-10W-30 standard lubricants was performed by mixing the three basic lubricants in a beaker glass, followed by a stirring process with a speed of $330 \mathrm{rpm}$ at $50^{\circ} \mathrm{C}$ for 60 minutes. $\mathrm{MoS}_{2}$ nanoparticles and SDS were added to the mixture with varying concentrations of optimum concentrations of $0.1 \%$ wt and $0.2 \% \mathrm{wt}$ respectively. The four-ball test indicated a $16 \%$ decrease in scar diameter in SAE-10W-30 standard lubricants that had been given $\mathrm{MoS}_{2}$ and SDS nanoparticles. Moreover, the results of the high-frequency reciprocating rig (HFRR) test showed a decrease in wear scar of around $42.7 \%$, a decrease in the coefficient of friction of $1.61 \%$, but an increase in film coating to $100 \%$. Based on these results, it can be concluded that $\mathrm{MoS}_{2}$ nanoparticles and SDS increase the engine wear protection in SAE-10W-30 standard mixture lubricants.
\end{abstract}

Keywords: Molybdenum Disulfide $\left(\mathrm{MoS}_{2}\right)$ Nanoparticles, Sodium Dodecyl Sulphate (SDS), Four-ball Scar Diameter, High-Frequency Reciprocating Rig (HFRR).

(C) RASĀYAN. All rights reserved

\section{INTRODUCTION}

Mechanical performance and damage to ordinary machining tools are often caused by friction, originating from $59.5 \%$ of the piston circuit, $23.7 \%$ of the valve mechanism, $8.8 \%$ of bearings, and $7.9 \%$ of other issues ${ }^{1}$. In this regard, the engine wear that is caused by friction increases the repairment and replacement of tools cost. Also, there will be an increase in overall energy use caused by high levels of energy lost due to friction. Therefore, reducing friction, especially by using a modified lubricant is one effective method ${ }^{2}$. With the addition of lubricants, it can increase the efficiency of energy use on the engine by $3-4 \%{ }^{1}$.

One way to improve the quality of the lubricant is to add nanoparticle-sized additives that can form thin films on the surface of metals in various machine components. These additives can be derived from organic or inorganic compounds, but in general, additives which are often used in lubricants are derived from ceramics and metals ${ }^{3}$. The use of nanoparticle-sized additives is intended to enter the inside of a very small machine; the additive works very well at room temperature and can be combined with other materials ${ }^{4}$. On the other hand, besides adding the nanoparticle-sized additives directly to the lubricant ${ }^{5-12}$, these substances can also be applied directly to the surface of the tested object and act as solid lubricants. ${ }^{13,14}$

Molybdenum disulfide $\left(\mathrm{MoS}_{2}\right)$ is a material that is widely used as a solid lubricant and also additive to lubricant oil. It shows high lubrication ability, good thermal stability, low friction characteristics, does not dissolve under high acid conditions, the ability to be able to work in a vacuum and dry lubrication, and inactivity to oxygen. The existence of low friction properties in $\mathrm{MoS}_{2}$ is due to the shape of crystal

Rasayan J. Chem., 13(2), 810-816(2020)

http://dx.doi.org/10.31788/RJC.2020.1325639

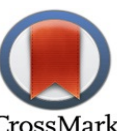


RASĀYAN J. Chem.

Vol. 13 | No. 2 |810 - 816| April - June | 2020

structure in the form of hexagonal crystal lattice structure with strong bonds in the hexagonal plane and Van der Waals bonds between sulfur atoms. This mechanism can be considered as graphite with a lamellar crystal structure that makes it function as a lubricant. Thus, the effectiveness of this material will increase with an increase in contact force with the lubricated component. ${ }^{13}$

The use of $\mathrm{MoS}_{2}$ as an additive in lubricating oils has been observed to be able to reduce the coefficient of friction. ${ }^{8,9,15,16}$ However, the addition of other additives such as sodium dodecyl sulfate (SDS) or polyisobutylene succinamide is needed to avoid buildup, produce better extreme pressure properties, and stabilize $\mathrm{MoS}_{2}$ nanoparticles in base oil ${ }^{9,17,18}$. To date, there has not been much research recorded towards the use of $\mathrm{MoS}_{2}$ and SDS additives in lubricating oils with SAE 10W-30 standards.

Therefore, this study aimed to analyze the effect of $\mathrm{MoS}_{2}$ and SDS powder's addition on a mixture of SAE 10W-30 standards. The lubricating oils are oils formulated from Yubase 8, HVI 95, and HVI 60 base oils with the addition of LZ 7075, Viscoplex PP, and LZ 19010. The selection of base oil was carried out because the three base oils have low quality, so this research was able to produce higher quality lubricating oils. Lastly, the analyzed characteristics were worn protection from lubricating oil.

\section{EXPERIMENTAL}

\section{Material and Methods}

The formulation was based on SAE 10W-30 (SAE and API Service) lubricant standards. The materials used were Base oil HVI-95 (Pertamina Indonesia), Base oil HVI-60 (Pertamina Indonesia), Yubase-8 base oil (produced by SK Energy Korea), LZ 7075, Viscoplex PP, and LZ 19010. Table-1 describes the characteristics of base oils.

Table-1: Base Oil Caharacteristics ${ }^{19}$

\begin{tabular}{l|l|l|l}
\hline Base Oil & Viscosity Index & Sulfuric Content (\%) & Saturation Level (\%) \\
\hline Yubase-8 & $\geq 120$ & $\leq 0.03$ & $\geq 90$ \\
\hline HVI 95 & 80 sampai 120 & $\leq 0.03$ & $\geq 90$ \\
\hline HVI 60 & 80 sampai 120 & $>0.03$ & $<90$ \\
\hline
\end{tabular}

Table-2 shows the characteristics of nano-sized $\mathrm{MoS}_{2}$ powders (MK Impex Corp. Canada) and SDS (Sigma Aldrich). Figure-1 displays the TEM image of a confirmed nanometer-sized $\mathrm{MoS}_{2}$ powder.

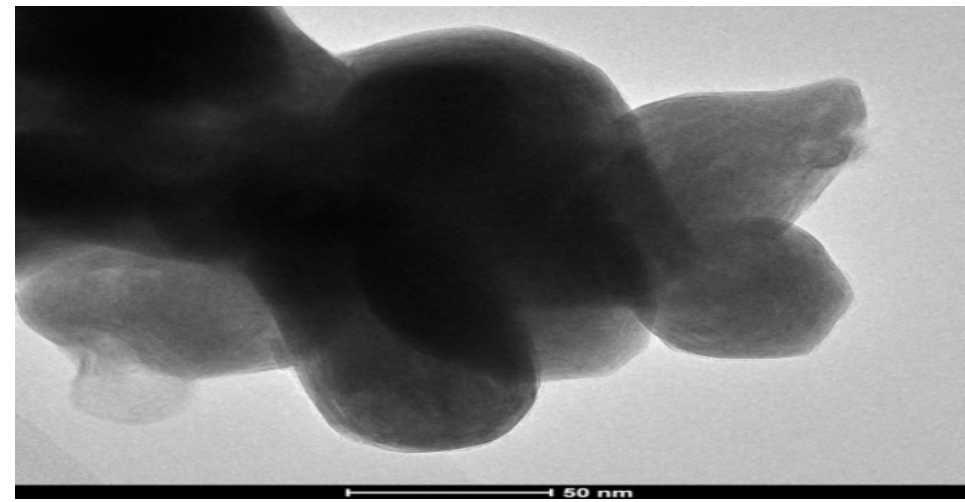

Fig.-1: TEM Photograph of $\mathrm{MoS}_{2}$ Nanoparticles

Table-2: $\mathrm{MoS}_{2}$ Nanoparticles and SDS Characteristics

\begin{tabular}{l|l|l}
\hline Material & Physical Properties & Value \\
\hline \multirow{4}{*}{ SDS } & Density & $1.01 \mathrm{~g} / \mathrm{cm}^{3}$ \\
\hline \multirow{4}{*}{$\mathrm{MoS}_{2}$} & Molar Mass & $288.38 \mathrm{~g} \mathrm{~mol}^{-1}$ \\
\cline { 2 - 3 } & Melting Point & $206^{\circ} \mathrm{C}$ \\
\cline { 2 - 3 } & Purity & $99.0 \%$ \\
\hline & SSA & $35 \mathrm{~m}^{2} / \mathrm{g}$ \\
\cline { 2 - 3 } & APS & $90 \mathrm{~nm}$ \\
\cline { 2 - 3 } & True Density & $5.06 \mathrm{~g} / \mathrm{cm}^{3}$ \\
\cline { 2 - 3 } & Bulk Density & $\sim 0.78 \mathrm{~g} / \mathrm{cm}^{3}$ \\
\cline { 2 - 3 } & Morphology & Nearly spherical \\
\hline
\end{tabular}

811 
RASĀYAN J. Chem.

Vol. 13 | No. 2 |810 - 816| April - June | 2020

Lubricating oil formulation with $\mathrm{MoS}_{2}$ nanoparticles and SDS additives was performed by mixing the basic lubricating oil, SDS and $\mathrm{MoS}_{2}$ nanoparticles in a beaker glass that was stirred at $330 \mathrm{rpm}$ and $50^{\circ} \mathrm{C}$ for 60 minutes. The ratio of $\mathrm{MoS}_{2}$ nanoparticles and SDS mixture was varied with the comparison given in Table-3.

Table-3: The Mixture Concentration Ratio of Lubricating Oil and $\mathrm{MoS}_{2}$ Nanoparticles and SDS

\begin{tabular}{l|l|l}
\hline Sample & Base Lubricating Oil & $\mathrm{MoS}_{2}+$ SDS(wt \%) \\
\hline SAE 10W-30 & $\begin{array}{l}\text { HVI 60, HVI 95, and Yubase 8 were } \\
\text { formulated to have an SAE 10W-30 } \\
\text { standard }\end{array}$ & - \\
\hline Mod SAE10W-30 & $\begin{array}{l}\text { HVI 60, HVI 95, dan Yubase 8 were } \\
\text { formulated to have an SAE 10W-30 } \\
\text { standard }\end{array}$ & $0.1+0.2$ \\
\hline HVI 60 & HVI 60 & $0.1+0.2$ \\
\hline HVI 95-1 & HVI 95 & $0.01+0.01$ \\
\hline HVI 95-2 & HVI 95 & $0.05+0.01$ \\
\hline HVI 95-3 & HVI 95 & $0.05+0.05$ \\
\hline HVI 95-4 & HVI 95 & $0.5+0.01$ \\
\hline HVI 95-5 & HVI 95 & $0.1+0.2$ \\
\hline HVI 95-6 & HVI 95 & $0.5+0.5$ \\
\hline Yubase 8-1 & Yubase 8 & $0.01+0.01$ \\
\hline Yubase 8-2 & Yubase 8 & $0.05+0.01$ \\
\hline Yubase 8-3 & Yubase 8 & $0.05+0.05$ \\
\hline Yubase 8-4 & Yubase 8 & $0.5+0.01$ \\
\hline Yubase 8-5 & Yubase 8 & $0.1+0.2$ \\
\hline Yubase 8-6 & Yubase 8 & $0.5+0.5$ \\
\hline
\end{tabular}

\section{Detection Method}

The wear resistance properties of the lubricating oil test were carried out using a four-ball test machine (Stanhope Sete) with the ASTM D 4172 test method at a load of $40 \pm 0.2 \mathrm{~kg}$, a speed of $1200 \mathrm{rpm}$, and test temperature of $75^{\circ} \mathrm{C}$ for 60 minutes. The test ball was a chromium alloy steel with $12.7 \mathrm{~mm}$ diameter and with AISI E-52100 (grade 25 EP (Extra Polish)) standard material. Also, it has a Rockwell C hardness level between 64-66. Lastly, the analyses were performed based on the size of the scratches from the test balls ${ }^{20}$.

The measurement of friction coefficient, film coating properties, and the diameter of the test object scratches was conducted with a High-Frequency Reciprocating Rig (HFRR) based on ASTM D 6079. The test discs were made of $10 \mathrm{~mm}$ steel (AISI E-52100) with Vickers hardness (HV 30 hardness) level according to E 92 specifications (scale 190-210). Discs were also coated, so that surface roughness was less than $0.02 \mu \mathrm{m} \mathrm{Ra}$. Furthermore, the test ball used was made of steel with a diameter of $6.00 \mathrm{~mm}$, AISI E-52100 Grade 24 standard per ANSI B3.12 and a Rockwell hardness scale of "C", scaling in the range of 58-66. Finally, the test method performed was E 18 with a surface roughness smaller than $0.05 \mu \mathrm{m} \mathrm{Ra}{ }^{20,21}$

\section{Analysis of the Four-ball Test}

\section{RESULTS AND DISCUSSION}

Figure-2 shows the scar diameter obtained from the four-ball test for each sample. It can be seen that the addition of $\mathrm{MoS}_{2}$ nanoparticles and SDS to the lubricating oil can reduce the diameter of the scar on the test ball. Based on the comparison of each sample (HVI 60, HVI 95, and Yubase 8), the optimum mixed concentrations was found at $0.1 \mathrm{wt} \% \mathrm{MoS}_{2}$ and $0.2 \mathrm{wt} \% \mathrm{SDS}$.

Although the use of $\mathrm{MoS}_{2}$ nanoparticles as additives can reduce friction in the metal, their use at too high concentrations can lead to agglomeration of $\mathrm{MoS}_{2}$ nanoparticles, especially if the SDS added has a smaller concentration than $\mathrm{MoS}_{2}$ nanoparticles. This can be observed from the samples of HVI 95-4 (0.5 wt $\% \mathrm{MoS}_{2}+0.01 \mathrm{wt} \%$ SDS $)$ and Yubase $8-4\left(0.5 \mathrm{wt} \% \mathrm{MoS}_{2}+0.01 \mathrm{wt} \% \mathrm{SDS}\right)$.

$\mathrm{MoS}_{2}$ nanoparticles are materials that can undergo oxidation more quickly if they have an increasingly smaller size. This is indicated by the formation of $\mathrm{MoO}_{3}$, which is abrasive ${ }^{13}$. Therefore, the lubricating 
RASĀYAN J. Chem.

Vol. 13 | No. 2 |810 - 816| April - June | 2020

oil which is added with a high concentration of $\mathrm{MoS}_{2}$ has a larger diameter of the scar on the test ball compared to other samples with the same type of lubricating oil.

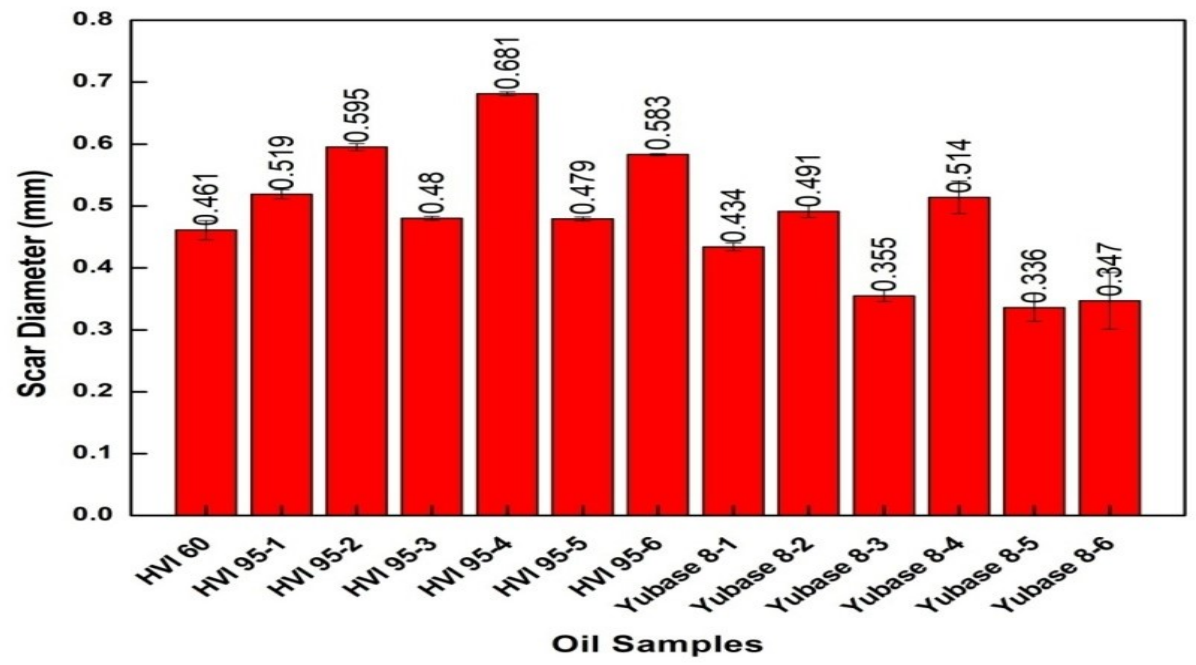

Fig.-2: Scar Diameter of HVI 60, HVI 95, and Yubase 8 Lubricants

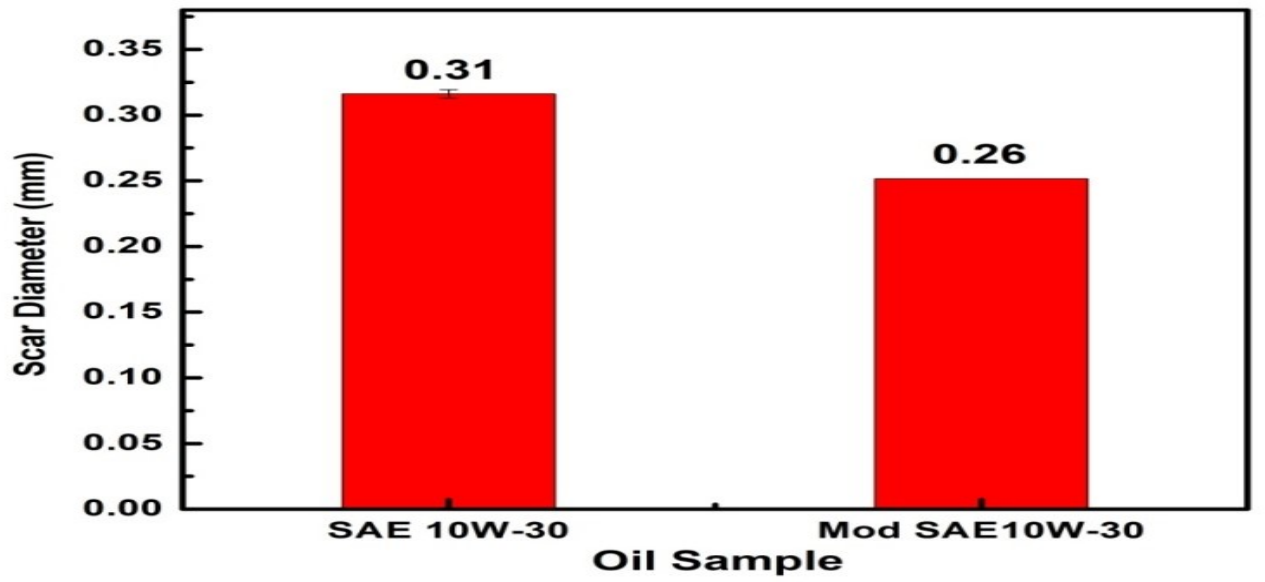

Fig.-3: Scar Diameter of Test Ball on Lubricating Oil Samples SAE 10W-30 with and without the Addition of $\mathrm{MoS}_{2}$ and SDS Nanoparticles

Based on Fig.-2 and Fig.-3, it can be seen that SAE 10W-30 lubricant has a scar diameter that is much smaller compared to the scar diameter of HVI 60, HVI 95, and Yubase 8, which is equal to $0.32 \mathrm{~mm}$. SAE 10W-30 lubricants are categorized as a lubricant with good wear protection standards. The addition of $\mathrm{MoS}_{2}$ nanoparticles and SDS only reduced the scar diameter to $0.25 \mathrm{~mm}$; in other words, the addition of $\mathrm{MoS}_{2}$ nanoparticles and SDS additives does not have much effect on SAE 10W-30 lubricants synthesized from basic lubricants HVI 60, HVI 95, and Yubase 8 and can only reduce scar diameter by $16 \%$.

\section{Analysis of HFRR Test}

HFRR test equipment was used to analyze the protection characteristics against machine wear as indicated by the coefficient of friction, wear scar, and film coating on the test ball. In this test, the friction coefficient and wear scar values were inversely proportional to the film coating value. Several factors that can affect the effectiveness of $\mathrm{MoS}_{2}$ nanoparticles in a lubricant that is applied to the engine are environmental humidity, working temperature, size, and the purity level of $\mathrm{MoS}_{2}$ additives ${ }^{22}$. Furthermore, the HFRR test results are displayed in Fig.-4, Fig.-5 and Fig.-6. 
RASĀYAN J. Chem.

Vol. 13 | No. 2 |810 - 816| April - June | 2020

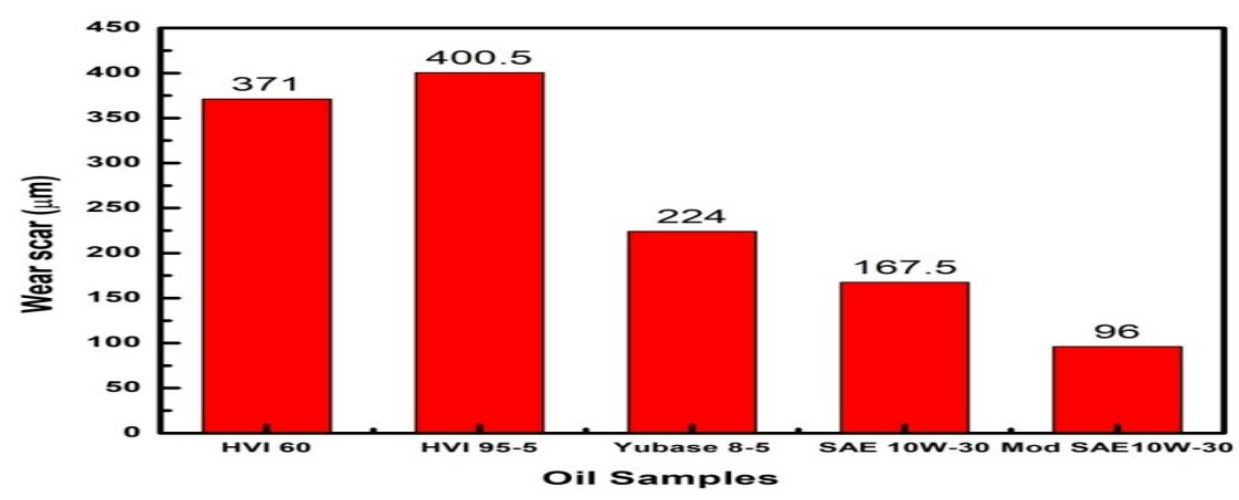

Fig.-4: Wear Scar Value on Test Ball

Based on Fig.-4, it can be seen that the addition of $\mathrm{MoS}_{2}$ nanoparticles to the lubricant reduces the value of wear scar by around $42.7 \%$; from $167.5 \mu \mathrm{m}$ to $96 \mu \mathrm{m}$. Also, it can be observed that the three basic lubricants used have large wear scar values. However, the three lubricants can be combined into SAE$10 \mathrm{~W}-30$ standard oils which have smaller wear scar values.

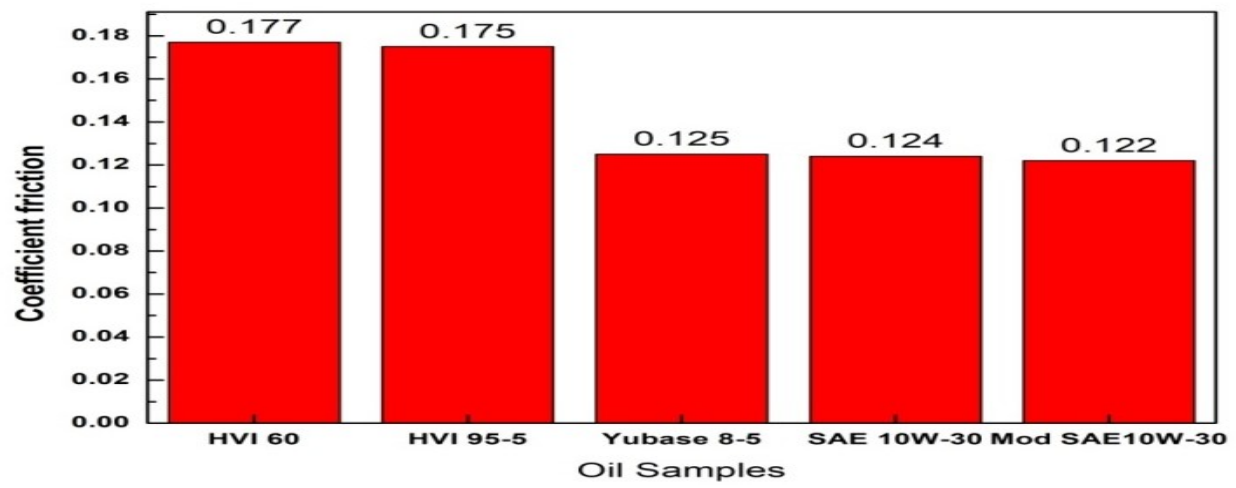

Fig.-5: Coefficient of Friction Value from HFRR Test

For the test results of the lubricating friction coefficient, Fig.-5 shows a decrease in the coefficient of friction from 0.24 to 0.122 with the addition of $\mathrm{MoS}_{2}$ nanoparticles, or a $1.61 \%$ decrease in the coefficient of friction. Furthermore, it can be seen that the Yubase- 8 extender is a lubricant with a small friction coefficient; the value is almost close to the SAE-10W-30 lubricant value. On the other hand, the other two base lubricants were found to possess a greater friction coefficient value. The combination of the three lubricants is proven to form a smaller friction coefficient value than each base lubricant.

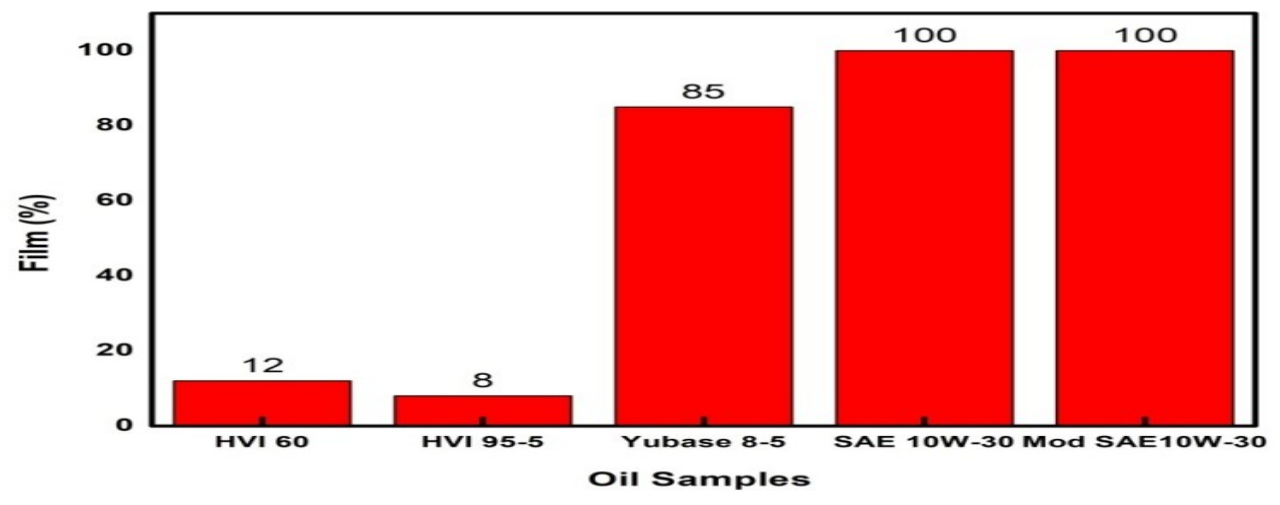

Fig.-6: Film Coating Value on Test Ball 
RASĀYAN J. Chem.

Vol. 13 | No. 2 |810 - 816| April - June | 2020

Based on Fig.-6, it appears that two basic lubricants, namely HVI-60 and HVI-95 have a very low percentage of film coating, which is $12 \%$ and $6 \%$, while Yubase- 8 has a high enough value, which is 85 $\%$. The combination of these three basic lubricants can increase the percentage of film coating on the test ball to $100 \%$. Also, the addition of $\mathrm{MoS}_{2}$ nanoparticles maintained the film coating value by $100 \%$.

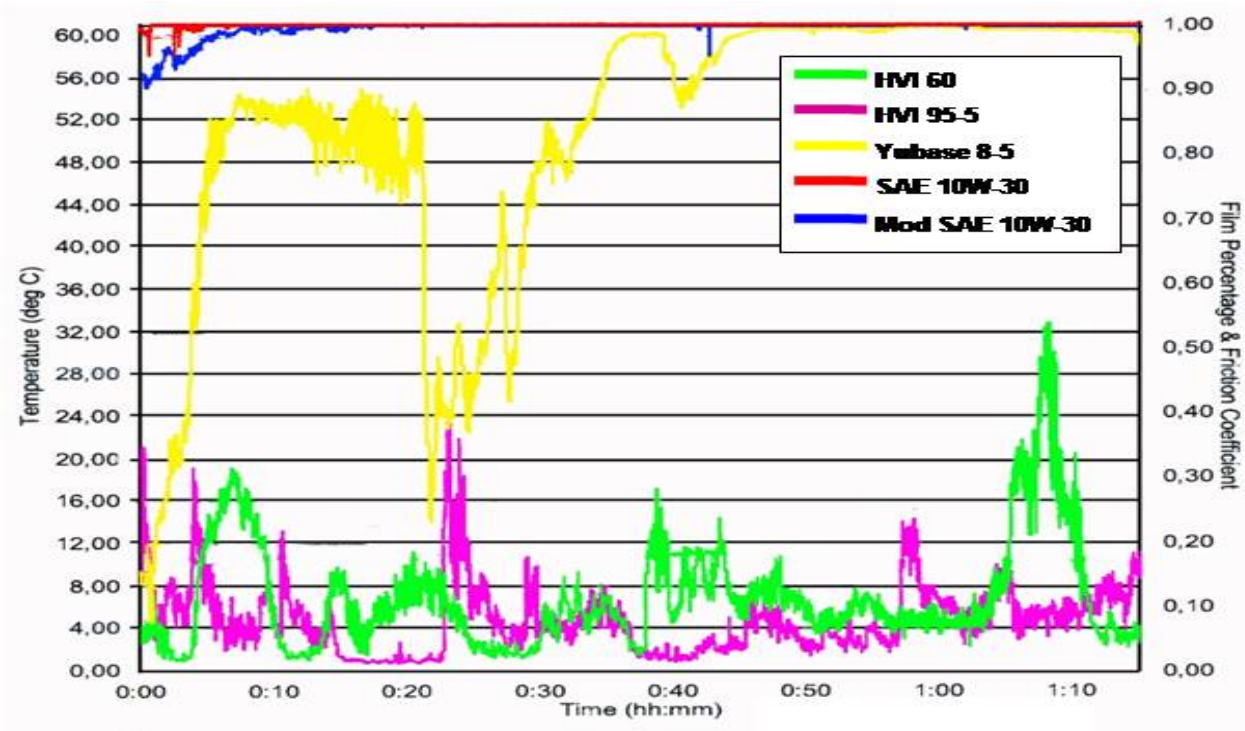

Fig.-7: Film Coating Graph

SAE-10W-30 lubricants, which were combined from three basic lubricants, provide a stable coating value of $100 \%$, as shown in Fig.-7. The addition of $\mathrm{MoS}_{2}$ nanoparticles and SDS gives the same results as pure SAE-10W-30 Lubricants. Meanwhile, the Yubase- 8 base lubricant took 40 minutes to provide a constant $100 \%$ coating film. Lastly, basic lubricants HVI-60 and HVI-95 provide an unstable film coating value.

\section{CONCLUSION}

The addition of $\mathrm{MoS}_{2}$ nanoparticles and SDS to SAE 10W-30 standard lubricants can reduce the coefficient of friction and wear scar, while increasing the percentage of film coating on the test ball. Also, it was discovered that the optimum concentration of $\mathrm{MoS}_{2}$ nanoparticles to be added to the lubricant was $0.1 \% \mathrm{wt}$, with a surfactant concentration of SDS of $0.2 \% \mathrm{wt}$.

\section{ACKNOWLEDGMENT}

This research was facilitated by the Center for Research and Development of Oil and Gas Technology, Oil and Gas Institute (PPPTMGB LEMIGAS), Indonesia.

\section{REFERENCES}

1. D. Pirro, M. Webster \& E. Daschner, Lubrication Fundamentals, Third Edition, Revised and Expanded, (2016), DOI:10.1201/b19217

2. G.W. Stachowiak and A. W. Batchelor, Engineering Trybology, Butterworth Heinemann, (2005).

3. S. Nallusamy and J. Logeshwaran, Rasayan Journal of Chemistry, 10(3), 1050(2017), DOI: 10.7324/RJC.2017.1031861

4. T. Mang and W. Dresel, Lubricants and Lubrication: Second Edition, (2007), DOI: $10.1002 / 9783527610341$

5. L. Rudnick, Lubricant Additives: Chemistry and Applications, CRC Press Taylor Fr. Gr., 796(2010).

6. M. K. Dubey, J. Bijwe and S. S. V. Ramakumar, Wear 306, 80(2013), DOI: 10.1016/j.wear.2013.06.020

7. M. Kalin, J. Kogovšek, and M. Remškar, Wear, 280-281, 36(2012), DOI: 10.1016/j.wear.2012.01.011 
RASĀYAN J. Chem.

Vol. 13 | No. 2 |810 - 816| April - June | 2020

8. J. Kogovšek, M. Remškar, A. Mrzel and M. Kalin, Tribology International, 61, 40(2013), DOI: 10.1016/j.triboint.2012.12.003

9. V. Srinivas, C. Kodanda Rama Rao, M. Abyudaya and E. S. Jyothi, Universal Journal of Mechanical Engineering, 2, 220(2017), DOI:10.13189/ujme.2014.020702

10. R. Krishna Sabareesh, N. Gobinath, V. Sajith, S. Das, \& C. B. Sobhan, International Journal of Refrigeration, 35, 1989(2012), DOI:10.1016/j.ijrefrig.2012.07.002

11. S. Ingole, et al, Wear 301, 776(2013), DOI:10.1016/j.wear.2013.01.037

12. D. Jiao, S. Zheng, Y. Wang, R. Guan and B. Cao, Applied Surface Science, 257, 5720(2011), DOI: 10.1016/j.apsusc.2011.01.084

13. J. Luo, M. H. Zhu, Y. D. Wang, J. F. Zheng and J. L. Mo, Tribology International, 44, 1565(2011), DOI: $10.1016 / j$.triboint.2010.10.011

14. W. Jiang, A. P. Malshe and W. D. Brown, Surface Coatings Technology, 177-178, 671(2004), DOI: 10.1016/s0257-8972(03)00893-4

15. R. A. Mufti et al., Tribology International, 88, 271(2015), DOI:10.1016/j.triboint.2015.03.035

16. M. I. H. C.Abdullah, M. Fadzli Abdollah, H. Amiruddin, N. Tamaldin and N. R. Mat Nuri, Jurnal Teknology (Sciences and Enggineering), 66, 1(2014), DOI:10.11113/jt.v66.2685

17. J. Sonali, N. Sandhyarani and V. Sajith , International Journal of Fluid Mechanics, 1, (2014), DOI: 10.15224/ 978-1-63248-028-6-03-84

18. Susilawati, M.Hanifuddin, Y.P. Gultom, Rasayan Journal of Chemistry, 12(3), 1043(2019), DOI: 10.31788/RJC.2019.1235166

19. Lubrizol. Ready Reference for Lubricant and Fuel Performance. (Lubrizol Corp., 2002).

20. D4172-94, A. Standard Test Method for Wear Preventive Characteristics of Lubricating Fluid ( FourBall Method ) 1, ASTM International, 94, 1-5 (2016).

21. ASTM International. D6079: Standard Test Method for Evaluating Lubricity of Diesel Fuels by the High-Frequency Reciprocating Rig (HFRR), American Society for Testing and Materials, 1-5 (2004). DOI: 10.1520/D6079-04E01.2

22. A. Hernández Battez et al., Wear, 265, 422(2008), DOI:10.1016/j.wear.2007.11.013

[RJC-5639/2019] 